Jurnal Ekonomi dan Industri

e-ISSN: 2656-3169

Volume 21, No.3, September-Desember 2020

p- ISSN: 0853-5248

\title{
PENGARUH KERAGAMAN PRODUK, HARGA DAN TEMPAT TERHADAP KEPUASAN PELANGGAN TOKO BUKU PAPERCLIP
}

\author{
Rizki Margiyatni ${ }^{1)}$ \\ 1) Mahasiswa Program Studi Manajemen FE UNKRIS \\ Siwi Nur Indriyani ${ }^{2)}$ \\ 2) Dosen Program Studi Manajemen FE UNKRIS \\ Alamat : Kampus UNKRIS, Jatiwaringin Jakarta Timur \\ Email : siwiindriyani76@gmail.com
}

\begin{abstract}
This study was conducted to determine the effect of product diversity, price and place on customer satisfaction in the Paperclip Book Store at Kota Kasablanka Mall. This study uses a quantitative approach. The population in this study were costumers who arrived at the Paperclip bookstore. The sampling technique in this study used a probability sampling or random sample, using the formula of Slovin. Data collection techniques in this study used a questionnaire. Data analysis method used in this study is multiple linear regression.
\end{abstract}

Keywords: Product diversity on price, place, customer satisfaction

\section{PENDAHULUAN}

Buku merupakan media pembelajaran dan sumber infomasi yang menempati posisi penting dalam peradaban manusia. Buku berperan penting dalam kemajuan di bidang pendidikan. Seiring dengan semakin baiknya tingkat pendidikan di Indonesia, permintaan akan buku cenderung meningkat. Toko Buku Paperclip pada mulanya hanya fokus pada penjualan produk buku dan stationery saja, namun saat ini ragam produknya sudah semakin berkembang, yaitu fancy, peralatan kantor, accessories, peralatan art dan lukisan serta produk-produk teknologi lainnya.

Keputusan pelanggan untuk membeli atau pun tidaknya terhadap suatu produk merupakan suatu tantangan dan masalah yang dihadapi Toko Buku Paperclip. Hal tersebut menyangkut pada keberlangsungan usaha yang dijalankan, sehingga mendorong pengelola untuk dapat meningkatkan strategi pemasaran dan mengamati perilaku pelanggan agar nantinya pelanggan mendapatkan pelayanan yang baik dan kemudian muncul kepercayaan dalam diri pelanggan terhadap Toko Buku Paperclip. Memahami perilaku pelanggan memang bukanlah perkara mudah, terlebih lagi setiap pelanggan memiliki berbagai macam selera dan berbagai harapan mengenai produk yang akan dibeli, suasana yang diperoleh, serta alasan untuk memilih toko ritel sebagai tempat berbelanja, hingga pada akhirnya melakukan keputusan pembelian.

Harga merupakan salah satu faktor penentu dalam pengambilan keputusan pelanggan. Harga produk tertentu di Toko Buku Paperclip cenderung lebih murah jika dibandingkan dengan produk-produk serupa di tempat ataupun toko lain, sehingga berpengaruh terhadap keputusan pembelian pelanggan. Pelanggan akan mempertimbangkan tempat berbelanja mana yang mampu memenuhi harapan dan kebutuhan mereka. Setiap harga yang ditetapkan oleh perusahaan juga akan mengakibatkan tingkat permintaan terhadap produk yang berbeda.

Tempat yang nyaman sangatlah penting bagi pelanggan saat berbelanja di toko buku Paperclip ini, karena toko buku ini menyiapkan tempat yang nyaman dengan desain yang 
bagus dan membuat pelanggan betah untuk terus berada di dalam toko. Dengan padanan warna dan juga tata produk yang baik menambah kesan bagus pada toko ini. Dan juga menjadi daya tarik untuk pelanggan selalu datang ke toko buku Paperclip.

Ramainya toko buku Paperclip dapat dilihat dari jumlah pengunjung yang tidak pernah sepi memadati area toko tiap harinya, terutama saat musim liburan tiba. Namun perlu dicermati lagi apakah seluruh pengunjung yang datang sudah pasti melakukan pembelian disana atau pengunjung hanya sekedar window shopping saja, mengingat pada saat ini Toko Buku Paperclip selain sebagai tempat berbelanja juga sebagai sarana untuk membaca buku dan sarana refreshing bagi pelanggan jaman sekarang. Buku merupakan media pembelajaran dan sumber infomasi yang menempati posisi penting dalam dalam peradaban manusia. Buku berperan berperan penting dalam kemajuan di bidang pendidikan. Seiring dengan semakin baiknya tingkst pendidikan di Indonesia, permintaan akan buku cenderung meningkat.

Tujuan penelitian ini adalah untuk mengetahui pengaruh kergaman produk, harga dan tempat terhadap kepuasan pelanggan Toko Buku Paperclip.

\section{LANDASAN TEORI}

\section{Keragaman Produk}

Menurut Kotler dalam buku Saladin (2012), "produk adalah segala sesuatu yang dapat ditawarkan ke suatu pasar untuk diperhatikan, dimiliki, dipakai, dan dikonsumsi sehingga dapat memuaskan keinginan dan kebutuhan pelanggan". Pendapat tersebut didukung pula oleh Kotler dan Amstrong (2012) yang mendefinisikan "produk sebagai segala sesuatu yang dapat ditawarkan kepada pelanggan agar menarik perhatian, akuisisi, penggunaan, atau konsumsi yang dapat memuaskan suatu keinginan dan kebutuhan". Lain halnya menurut Stanton yang dikutip dan dialih dahasakan oleh Alma (2010), "produk sebagai seperangkat atribut baik berwujud maupun tidak berwujud, termasuk didalamnya masalah warna, harga, nama baik pabrik, nama baik toko yang menjual (pengecer), dan layanan pabrik serta pelayanan pengecer, yang diterima oleh pembeli guna memuaskan keinginannya". Indikator keragaman produk menurut Kotler dan Keller (2015) adalah lebar bauran produk, panjang bauran produk, kedalaman bauran produk, dan konsistensi dari bauran produk.

\section{Harga}

Kotler dan Keller (2012), menyatakan "prices should reflect the value consumers are willing to pay versus prices should reflect only the cost of making a product or delivering a service". Maksud dari pengertian tersebut adalah harga harus mencerminkan nilai konsumen bersedia membayar harga dibandingkan harus mencerminkan hanya biaya pembuatan produk atau memberikan layanan. Menurut Stanton yang dikutip oleh Laksana (2010) menyatakan bahwa "harga adalah jumlah uang (kemungkinan ditambah beberapa barang) yang dibutuhkan untuk memperoleh beberapa kombinasi sebuah produk dan pelayanan yang menyertainya". Definisi tersebut sejalan dengan pendapat Alma (2011) yang mendefinisikan "harga (price) sebagai nilai suatu barang yang dinyatakan dengan uang". Harga memiliki dua peranan utama dalam proses pengambilan keputusan para pembeli, yaitu peranan alokasi dan peranan informasi. Indikator harga menurut Kotler dan Amstrong (2008 ) adalah keterjangkauan harga, kesesuaian harga dengan kualitas produk, daya saing harga, dan kesesuaian harga dengan manfaat. 


\section{Tempat}

Lokasi menurut Tjiptono (2015) "mengacu pada berbagai aktivitas pemasaran yang berusaha memperlancar dan mempermudah penyampaian atau penyaluran barang dan jasa dari produsen kepada konsumen", sedangkan menurut Kotler dan Amstrong (2014) "place include company activities that make the product available to target consumers". Kemudian menurut Lupiyoadi dan Hamdani (2011), "lokasi adalah keputusan yang dibuat perusahaan atau instansi pendidikan berkaitan dengan di mana operasi dan stafnya akan ditempatkan". Pendapat mengenai lokasi dari para ahli tersebut, sampai pada pemahaman bahwa lokasi adalah suatu keputusan perusahaan untuk menentukan tempat usaha, menjalankan kegiatan usaha atau kegiatan operasional, dan mendistribusikan barang atau jasa yang menjadi kegiatan bisnisnya kepada pelanggan. Pentingnya lokasi bagi perusahaan atau pengusaha sangat mempengaruhi keputusan sasaran pasar dalam menentukan keputusan pembelian. Indikator lokasi menurut Huriyati (2015) adalah akses, visibilitas, lalu lintas, tempat parkir yang luas dan aman, ekspansi, tersedia tempat yang cukup untuk memperluas usaha dikemudian hari, lingkungan, persaingan dan peraturan pemerintah.

\section{Kepuasan Pelanggan}

Kotler dan Keller (2014) mengatakan bahwa kepuasan konsumen adalah perasaan senang atau kecewa seseorang yang muncul setelah membandingkan kinerja (hasil) jasa yang diperkirakan terhadap kinerja yang diharapkan. Menurut Tse dan Wilton dalam Tjiptono (2012), kepuasan pelanggan merupakan respon pelanggan terhadap evaluasi persepsi atas perbedaan antara harapan awal sebelum pembelian (atau standar kinerja lainnya) dan kinerja aktual produk sebagaimana dipersepsikan setelah memakai atau mengkonsumsi produk bersangkutan. Kepuasan pelanggan bukanlah konsep absolut, melainkan relatif atau tergantung pada apa yang diharapkan pelanggan. Indikator kepuasan pelanggan menurut Oliver dalam Tjiptono (2012), adalah perasaan yang timbul setelah mengevaluasi pengalaman pemakaian produk, respon pelanggan, evaluasi purnabeli, ukuran kinerja produk, dan tingkat perasaan.

\section{METODE PENELITIAN}

Menurut Sugiyono (2013), metode penelitian merupakan cara ilmiah untuk mendapatkan data dengan tujuan tertentu. Populasi dalam penenlitian ini adalah pelanggan toko buku Paperclip. Karena begitu banyak pelanggan yang mengunjungi toko buku Paperclip setiap harinya, pengumpulan data melalui penyebaran kuesioner selama seminggu di toko buku Paperclip ini, sehingga menghasilkan sebanyak 300 pelanggan sebagai populasi responden yang bersedia membantu mengisi kuesioner tersebut. Pengambilan sampel dalam penelitian ini dengan teknik probability sampling yaitu random sampling dengan menggunakan rumus Slovin. Menurut Sugiyono (2013), probability sampling adalah teknik pengambilan sampel yang memberikan peluang yang sama bagi setiap unsur (anggota) populasi untuk dipilih menjadi anggota sampel. Dengan demikian, sampel yang digunakan sebanyak 100 pelanggan sebagai sampel. Teknik analisis data yang digunakan dalam penenlitian ini adalah analisis regresi linear sederhana dan berganda, namun sebelum dianalisis dilakukan pengujian asumsi dasar, seperti uji normalitas dan uji linearitas. 


\section{HASIL PENELITIAN DAN PEMBAHASAN}

\section{Hasil Penelitian}

\section{Hasil uji normalitas}

Uji normalitas biasanya untuk mengukur data berskala ordinal, interval, maupun rasio. Perhitungan umumnya dilakukan dengan uji one sample Kolmogorof-Smirnov dengan taraf signifikansi 0,05, sehingga data dapat disimpulkan terdistribusi dengan normal jika signifikansinya lebih besar dari 0,05 (5\%). Menurut Santoso (2012), dasar pengambilan keputusan bisa dilakukan berdasarkan probabilitas (asymtotic significance), yaitu: 1) Jika probabilitas > 0,05, maka distribusi dari model regresi adalah normal. 2) Jika probabilitas < 0,05, maka distribusi dari model regresi adalah tidak normal. Berdasarkan hasil uji Kolmogorov-Smirnov, dapat dilihat bahwa model tersebut menunjukkan data terdistribusi secara normal, hal ini dibuktikan oleh nilai signifikansi sebesar 0,907, dimana nilai tersebut lebih besar dari 0,05 yang merupakan batas minimum signifikansi pada uji ini, maka dapat disimpulkan bahwa model tersebut memiliki distribusi yang normal.

\section{Hasil uji linearitas}

Uji linearitas dilakukan dengan menggunakan analisis variansi terhadap garis regresi yang nantinya akan diperoleh harga. Nilai $\mathrm{F}$ yang diperoleh kemudian dikonsultasikan dengan nilai pada taraf signifikan 5\%. Kriterianya apabila nilai $\mathrm{F}$ lebih kecil atau sama dengan pada taraf signifikan 5\%, maka hubungan antara variabel bebas dikatakan linier. Sebaliknya, apabila lebih besar dari pada, maka hubungan variabel bebas terhadap variabel terikat tidak linier (Nurgiyantoro, 2012). Berdasarkan nilai signifikasi, diperoleh nilai signifikasi pada linearity sebesar 0,000 lebih kecil dari 0,05 artinya ada hubungan yang linier antara variabel bebas (keragaman produk, harga dan tempat) dengan variabel terikat (kepuasan pelanggan).

\section{Analisis regresi berganda}

\section{Tabel-1: Pengaruh Keragamam Produk, Harga dan Tempat terhadap Kepuasan Pelanggan}

\begin{tabular}{lccccc}
\hline \multirow{2}{*}{ Variabel } & R-Square & Konstanta & $\begin{array}{c}\text { Koefisien } \\
\text { Regresi }\end{array}$ & Sig. & $\boldsymbol{\alpha}$ \\
\cline { 2 - 6 } & \multirow{2}{*}{0.942} & 0.873 & 0.610 & 0.000 & \\
\hline Produk & & & -0.184 & 0.000 & 0.05 \\
Harga & & & & & \\
Tempat & & & & & \\
\hline
\end{tabular}

\section{Pengujian Signifikansi}

F-hitung $=517.857>$ F-tabel $=2.399$

Sumber: data diolah 2019

Persamaan regresi linear: $\mathrm{Y}=0,873+0,610 \mathrm{X}_{1}+0,265 \mathrm{X}_{2}-0,184 \mathrm{X}_{3}$

Berdasarkan tabel-1, nilai F-hitung sebesar 517.857 menunjukkan bahwa secara bersama-sama keragaman produk, harga dan tempat berpengaruh signifikan terhadap kepuasan pelanggan toko buku Paperclip Kasablanka. Nilai koefisien determinasi $(R-$ Square) adalah sebesar 0,942 atau 94,2\%. Hasil ini menunjukkan bahwa kontribusi keragaman produk, harga dan tempat kepada kepuasan pelanggan adalah sebesar 94,2\%, 
dan sisanya sebesar $5,8 \%$ dijelaskan oleh variabel lainnya dan tidak dimasukkan dalam penelitian ini.

Keragaman produk, harga dan tempat berpengaruh signifikan terhadap kepuasan pelanggan toko buku Paperclip Kasablanka. Nilai koefisien regresi keragaman produk bertanda positif sebesar 0,610 , yang maknanya, jika keragaman produk meningkat, maka kepuasan pelanggan juga meningkat atau sebaliknya dengan asumsi harga dan tempat tidak berubah. Nilai koefisien regresi harga bertanda positif sebesar 0,265 , yang maknanya, jika harga membaik, maka kepuasan pelanggan juga meningkat atau sebaliknya dengan asumsi keragaman produk dan tempat tidak berubah. Nilai koefisien regresi tempat bertanda negatif sebesar -0,184, yang maknanya, jika tempat strategis, maka kepuasan pelanggan belum tentu meningkat atau sebaliknya dengan asumsi keragaman produk dan harga tidak berubah. Dengan demikian hipotesis pertama dapat diterima.

\section{Analisis regresi sederhana}

Tabel-2: Pengaruh Keragaman Produk terhadap Kepuasan Pelanggan

\begin{tabular}{lccccc}
\hline \multirow{2}{*}{ Variabel } & R-Square & Konstanta & $\begin{array}{c}\text { Koefisien } \\
\text { Regresi }\end{array}$ & Sig & A \\
\cline { 2 - 6 } & 0,919 & 1,330 & 0,656 & 0,000 & 0.05 \\
\hline Produk & & & & & \\
\hline Pengujian Signifikan & & & & &
\end{tabular}

Persamaan regresi $\mathrm{Y}=1,330+0,656 \mathrm{X}_{1}$

Berdasarkan tabel-2, nilai koefisien determinasi $\left(\mathrm{R}^{2}\right)$ sebesar 0.919 , artinya keragaman produk memberikan kontribusi sebesar 91,9\% kepada kepuasan pelanggan toko buku Paperclip Kasablanka, sedangkan sisanya sebesar 8,1\% disumbangkan faktor lain, seperti harga, tempat, dan lain-lain. Keragaman produk berpengaruh positif terhadap kepuasan pelanggan toko buku Paperclip Kasablanka. Koefisien keragaman produk bertanda positif sebesar 0,656, artinya jika ada peningkatan keragaman produk, maka kepuasan pelanggan toko buku Paperclip Kasablanka akan meningkat atau sebaliknya. Dengan demikian hipotesis kedua dapat diterima.

Untuk menguji hubungan secara parsial keragaman produk terhadap kepuasan pelanggan toko buku Paperclip Kasablangka signifikan atau tidak, dilakukan pengujian thitung dibandingkan dengan t-tabel dengan tingkat $\alpha=0,05$. Berdasarkan perhitungan dapat dinyatakan bahwa nilai t-hitung sebesar 33,317 lebih besar dari t-tabel, yaitu sebesar 1,985, maka dapat diartikan bahwa keragaman produk berpengaruh signifikan pada tingkat nyata 99\% terhadap kepuasan pelanggan toko buku Paperclip Kasablangka.

Tabel-3: Pengaruh Harga terhadap Kepuasan Pelanggan

\begin{tabular}{lccccc}
\hline \multirow{2}{*}{ Variabel } & R-Square & Konstanta & $\begin{array}{c}\text { Koefisien } \\
\text { Regresi }\end{array}$ & Sig & $\boldsymbol{\alpha}$ \\
\cline { 2 - 6 } & 0,816 & 1,376 & 0,683 & 0,000 & 0.05 \\
\hline Harga & & & & \\
\hline Pengujian Signifikan & \multicolumn{5}{c}{ Parameter } \\
\hline t-hitung = 20.866 $>$ t-tabel =1.985 & & & & \\
\hline Sumber: Data primer, diolah, 2019 & & &
\end{tabular}


Persamaan regresi $\mathrm{Y}=1,376+0,683 \mathrm{X}_{2}$

Berdasarkan tabel-3, nilai koefisien determinasi $\left(\mathrm{R}^{2}\right)$ sebesar 0.816 , artinya harga memberikan kontribusi sebesar 81,6\% kepada kepuasan pelanggan toko buku Paperclip Kasablanka, sedangkan sisanya sebesar 8,4\% disumbangkan faktor lain, seperti keragaman produk, tempat, dan lain-lain. Harga berpengaruh positif terhadap kepuasan pelanggan toko buku Paperclip Kasablanka. Koefisien harga bertanda positif sebesar 0,683, artinya jika harga membaik, maka kepuasan pelanggan toko buku Paperclip Kasablanka akan meningkat atau sebaliknya. Dengan demikian hipotesis ketiga dapat diterima.

Untuk menguji hubungan secara parsial variabel harga terhadap kepuasan pelanggan toko buku Paperclip Kasablangka signifikan atau tidak, dilakukan pengujian t-hitung dibandingkan dengan t-tabel dengan tingkat $\alpha=0,05$. Berdasarkan perhitungan dapat dinyatakan bahwa nilai t-hitung sebesar 20,866 lebih besar dari t-tabel, yaitu sebesar 1,985, maka dapat diartikan bahwa harga berpengaruh signifikan pada tingkat nyata $99 \%$ terhadap kepuasan pelanggan toko buku Paperclip Kasablangka.

Tabel-4: Pengaruh Tempat terhadap Kepuasan Pelanggan

\begin{tabular}{lccccc}
\hline \multirow{2}{*}{ Variabel } & R-Square & Konstanta & $\begin{array}{c}\text { Koefisien } \\
\text { Regresi }\end{array}$ & Sig & $\boldsymbol{\alpha}$ \\
\cline { 2 - 6 } & 0,735 & 2,649 & 0,591 & 0,000 & 0.05 \\
\hline Tempat & & & & \\
\hline Pengujian Signifikan & & & & \\
\hline t-hitung = 16.479 $>$ t-tabel $=1.985$ & & &
\end{tabular}

Persamaan regresi $\mathrm{Y}=2,649+0,591 \mathrm{X}_{3}$

Berdasarkan tabel-4, nilai koefisien determinasi $\left(\mathrm{R}^{2}\right)$ sebesar 0.735 , artinya tempat memberikan kontribusi sebesar 73,5\% kepada kepuasan pelanggan toko buku Paperclip Kasablanka, sedangkan sisanya sebesar 26,5\% disumbangkan faktor lain, seperti keragaman produk, harga, dan lain-lain. Tempat berpengaruh positif terhadap kepuasan pelanggan toko buku Paperclip Kasablanka. Koefisien tempat bertanda positif sebesar 0,591, artinya jika tempat strategis, maka kepuasan pelanggan toko buku Paperclip Kasablanka akan meningkat atau sebaliknya. Dengan demikian hipotesis keempat dapat diterima.

Untuk menguji hubungan secara parsial tempat terhadap kepuasan pelanggan toko buku Paperclip Kasablangka signifikan atau tidak, dilakukan pengujian t-hitung dibandingkan dengan t-tabel dengan tingkat $\alpha=0,05$. Berdasarkan perhitungan dapat dinyatakan bahwa nilai t-hitung sebesar 16,479 lebih besar dari t-tabel, yaitu sebesar 1,985, maka dapat diartikan tempat berpengaruh signifikan pada tingkat nyata $99 \%$ terhadap kepuasan pelanggan toko buku Paperclip Kasablangka.

\section{Pembahasan}

\section{Pengaruh produk, harga dan tempat terhadap kepuasan pelanggan Toko Buku} Paperclip Kasablanka

Keragaman produk, harga dan tempat secara bersama-sama mendorong peningkatan pepuasan pelanggan. Hasil penelitian ini sama dengan hasil penelitian yang dilakukan oleh Mongkau, et al, (2017), Agestina dan Susilowati (2019), yang menyatakan bahwa produk, 
harga dan tempat dapat mendorong peningkatan kepuasan pelanggan.

\section{Pengaruh keragaman produk terhadap kepuasan pelanggan Toko Buku Paperclip Kasablanka}

Keragaman produk mendorong peningkatan kepuasan pelanggan, hal ini dikarenakan keragaman produk menjadi daya tarik tersendiri oleh para pelanggan. Hasil penelitian ini sama dengan hasil penelitian yang dilakukan oleh Sari dan Setiyowati (2017), dan Hadita (2018), yang menyatakan bahwa keragaman kualitas produk dapat mendorong peningkatan kepuasan pelanggan.

\section{Pengaruh harga terhadap kepuasan pelanggan Toko Buku Paperclip Kasablanka}

Harga yang wajar mendorong peningkatan kepuasan pelanggan, hal ini dikarenakan harga wajar yang diberikan pada para pelanggan dapat terjangkau dan relatif lebih murah. Hasil penelitian ini sama dengan hasil penelitian yang dilakukan oleh Setyo (2017), yang menyatakan bahwa harga yang diberikan pada pelanggan dapat mendorong peningkatan kepuasan pelanggan.

\section{Pengaruh tempat terhadap kepuasan pelanggan Toko Buku Paperclip Kasablanka}

Tempat strategis mendorong peningkatan kepuasan pelanggan, hal ini dikarenakan tempat strategis dan mudah dijangkau oleh para pelanggan. Hasil penelitian ini sama dengan hasil penelitian yang dilakukan oleh Mukhlis (2019).

\section{KESIMPULAN DAN SARAN}

\section{Kesimpulan}

Berdasarkan hasil penelitian dan pembahasan, kesimpulan dalam penelitian ini adalah sebagai berikut: 1) Secara bersama-sama produk, harga dan tempat mendorong peningkatan kepuasan pelanggan pada Toko Buku Paperclip Kasablangka. 2). Keragaman produk mendorong peningkatan kepuasan pelanggan Toko Buku Paperclip Kasablangka. 3). Harga yang wajar mendorong peningkatan kepuasan pelanggan Toko Buku Paperclip Kasablangka. 4). Tempat strategis mendorong peningkatan kepuasan pelanggan Toko Buku Paperclip Kasablangka.

\section{Saran}

Saran-saran dalam penelitian ini yang mungkin dapat dijadikan sebagai bahan pertimbangan adalah sebagai berikut: 1) Bagi pengembangan ilmu; Perlu menjadi pertimbangan bahwa hasil penelitian ini dapat dikembangkan lebih lanjut, terutama dalam pengembaangan ilmu manajemen pemasaran pada umumnya, dan keragaman produk, harga dan tempat terhadap kepuasan pelanggan khususnya. 2) Bagi penelitian selanjutnya; Perlu menjadi pertimbangan bagi penelitian selanjutnya, terutama, mahasiswa yang hendak melakukan penelitian lebih lanjut mengenai keragaman produk, harga dan tempat terhdap kepuasan pelanggan agar mengkaji variabel yang belum diteliti dalam penelitian ini dengan menambah variabel seperti promosi, produksi dan distribusi. 3) Perlu menjadi pertimbangan bagi perusahaan melalui berbagai perbaikan berkelanjutan terutama yang berkenaan dengan: a) Indikator keragaman produk yang memberikan nilai terendah terhadap pembentukan variabel kepuasan pelanggan, yaitu variasi produk di toko paperclip sangat beragam dengan cara melakukan penambahan variasi produk baru di toko Paperclip akan menambah kepuasan pelanggan. b) Indikator harga memberikan nilai cukup rendah terhadap pembentukan variabel kepuasan pelanggan, yaitu harga produk sesuai dengan 
manfaat, yaitu tentukan nilai atau harga sesuai manfaat yang dapat di rasakan oleh pelanggan sehingga adanya kepuasan pelanggan di toko paperclip. c) Indikator tempat yang memberikan nilai terendah terhadap pembentukan variable kepuasan pelanggan, yaitu kesulitan mencari produk dimana toko harus memberikan berbagai kemudahan dalam penataan produk sehingga produk mudah untuk di temui oleh pelanggan, sehingga terjadinya kepuasan pelanggan di toko paperclip.

\section{DAFTAR PUSTAKA}

Agestina, Khussnul dan Susilowati, Ika. 2019. Analisis Pengaruh Lokasi, Harga dan Kualitas Produk Terhadap Kepuasan Konsumen Pada Konsumen Hanna Kebab Di Kebumen. Jurnal Ilmiah Mahasiswa Manajemen, Bisnis dan Akuntansi. Vol. 1, No. 1 Oktober 2019. Hal. 102-121.

Ali, Hasan. 2013. Marketing dan Kasus-Kasus Pilihan. Yogyakarta: CAPS (Center For Academic Publishing Service).

Alma, Buchari. 2011. Manajemen Pemasaran dan Pemasaran Jasa, Cetakan Kesembilan. Bandung: Alfabeth.

Arikunto, S. 2013. Prosedur Penelitian Suatu Pendekatan Praktik. Edisi Revisi. Jakarta: PT. Rineka Cipta.

Ghozali, Imam. 2011. “Aplikasi Analisis Multivariate Dengan Program SPSS”. Semarang: Badan Penerbit Universitas Diponegoro.

Hadita. 2018. Dampak Kwragaman Produk Terhadap Kepuasan Pelanggan Ramayana Departemen Store. Jurnal Riset manajemen dan Bisnis (JRMB) Fakultas Ekonomi UNIAT. Vol. 3, No. 3 Oktober 2018: 365-374. P-ISSN: 2527-7502; E-ISSN: 25812165.

Kotler, Philip \& Armstrong, Gerry. 2014. Principle Of Marketing, 15th edition. New Jersey: Pearson Pretice Hall.

Kotler, Philip and Keller, Kevin Lane. 2016. "Marketing Managemen, 15th Edition, Pearson Education,Inc".

Ladjamudin, Bin, Al-Bahra. 2005. Analisis dan Desain Sistem Informasi. Yogyakarta: Graha Ilmu.

Lupiyoadi, Rambat dan Hamdani, A, 2011. Manajemen Pemasaran Jasa. Edisi Kedua, Jakarta: Salemba Empat.

Mongkau, Gladis., Kawet, Lotje dan Sepang, Jantje. 2017. Pengaruh Kualitas Produk, Harga, dan Tempat Terhadap Kepuasan Konsumen Pada Pasar Tradisional Remboken (Studi Kasus Pada Masyarakat Desa Sinuian Kec. Remboken). Jurnal EMBA. Vol. 5 No. 2 Juni 2017. Hal. 2469-2477.

Mullins, John W dan Walker Jr, Orville C. 2013. Marketing Management: A Strategic Decision-Making Approach, 8th Edition, McGraw-Hill International Edition.

Mukhlis, M. Aziz. Pengaruh Lokasi dan Lualitas Pelayanan Terhadap Kepuasan Pelanggan Pada Jasa Pingiriman J \& T di Muara Bulian. Ekonomis: Journal of Economics and Business, 3 (1), 1-9. ISSN: 2597-8829 (Online).

Mursid, M. (2014). Manajemen Pemasaran. Jakarta: Bumi Aksara.

Nazir, Mohammad. 2011. Metode Penelitian. Jakarta: Ghalia Indonesia

Saladin, Djaslim. 2012. Manajemen Pemasaran Analisis, Perencanaan, Pelaksanaan dan Pengendalian. Edisi Ketiga. Bandung: CV. Linda Karya.

Sangadji, E.M., dan Sopiah. 2013. Prilaku Konsumen: Pendekatan Praktis Disertai: Himpunan Jurnal Penelitian. Yogyakarta: Penerbit Andi. 
Santoso, Singgih. 2010. Statistik Parametrik, Konsep dan Aplikasi dengan SPSS. Cetakan Pertama, PT Elex Media Komputindo. Jakarta: PT Gramedia.

Sari, Novita dan Setiyowati, Selfi. 2017. Pengaruh Keragaman Produk dan Kualitas Pelayanan Terhadap Kepuasan Konsumen di PB Swalayan Metro. Jurnal Manajemen Magister, Vol. 03. No. 02 Juli 2017. Hal. 186-199.

Setyo, Purnomo Edwin. 2017. Pengaruh Kualitas Produk dan Harga Terhadap Kepuasan Konsumen Best Autoworks. Jurnal Manajemen Dan Start-Up Bisnis. Volume 1, Nomor 6, Februari 2017. Hal. 755-764.

Sugiyono. 2015. Metode Penelitian Kombinasi (Mix Methods). Bandung: Alfabeta.

Sunyoto. Danang. 2014. Konsep Dasar Riset Pemasaran \& Perilaku Konsumen. Yogyakarta: CAPS.

Terry, George R dalam Afifudin 2013. "Principles of Management". 5 th Edition. Indonesia: Pearson.

Tjiptono, Fandy. 2011. Strategi Pemasaran. Edisi 3. Yogyakarta: ANDI.

Tjiptono, Fandy. 2012. Service Management Mewujudkan Layanan Prima. Yogyakarta: CV Andi Offset. 